\title{
KINETICS OF RHEOLOGICAL CHARACTERISTICS OF FOAM CONCRETE MIXTURE
}

\author{
${ }^{1}$ Martynov V., Doctor of Technical Sciences, Associate Professor, \\ ogasa_psk@ukr.net, ORCID: 0000-0002-9674-7920 \\ ${ }^{2}$ Martynova O., Ph.D., Associate Professor, \\ pingu_@ukr.net, ORCID: 0000-0001-7324-2543 \\ ${ }^{3}$ Elkin V.V., Head of project department, \\ vladislav.elkin.ogasa@gmail.com, ORCID: 0000-0001-5725-4763 \\ ${ }^{1}$ Makarova S., Ph.D., Associate Professor, \\ svetlana.makarova@ukr.net, ORCID: 0000-0003-3237-1431 \\ ${ }^{1}$ Kazmirchuk N., Ph.D., Senior teacher, \\ nkazmirchuk8@gmail.com, ORCID: 0000-0003-0930-2059 \\ ${ }^{1}$ Odessa State Academy of Civil Engineering and Architecture \\ 4, Didrichson street, Odessa, 65029, Ukraine \\ ${ }^{2}$ Odessa State Agrarian University \\ 13, Panteleimonovskaya st., Odessa, 65074, Ukraine \\ ${ }^{3} L L C$ «TD Inkraft», \\ 8, per. Gas, Odessa, 65000, Ukraine
}

\begin{abstract}
The results of experimental studies are presented, the purpose of which was to study the influence of variable formulation and technological factors on the rheological characteristics of the foam concrete mixture, in particular, the structural strength. This is preceded by an analysis of the process of structure formation of cellular concrete. As a result, it is shown that the properties of cellular concrete are determined by the nature of the distribution of the solid component. The structure of the solid phase is formed at the earliest stages of the formation of cellular products and depends on the rheological characteristics of the mortar and cellular mixture. In the technology of cellular concrete, it is important to synchronize the processes of pore formation and the growth of plastic (structural) strength, which is also associated with a change in the rheological properties of the mixture. Using the methods of mathematical statistics, the influence of the content of the filler in the mixture with cement, the content of the complex additive, and the effect of mechanical chemical activation on the kinetics of the plastic strength of the foam concrete mixture were studied. The kinetic dependences of the plastic strength of the foam concrete mixture in the range of $6 \ldots 24$ hours from the moment of manufacture have been constructed. Each of the 15 curves is maximized by a 3rd-degree polynomial. Based on the obtained dependences, they are differentiated between the first and second derivatives. As a result, the equations of the speed and intensity (acceleration) of the plastic strength of the foam concrete mixture were obtained. According to the results of the previous experiment, carried out according to a threefactor plan, a 4-factor plan was synthesized, in which the aging period of the foam concrete mixture was taken as the fourth factor. The calculated theoretical values of the characteristics of the structural strength of the foam concrete mixture were entered into the matrix. As a result, mathematical models of plastic strength, speed, and intensity of plastic strength of the foam concrete mixture were calculated and the influence of variable factors studied on the isosurfaces of these properties was visualized. The analysis of these dependencies made it possible to determine the characteristic recipe and technological conditions for obtaining a foam concrete mixture with the required values of plastic strength.
\end{abstract}

Keywords: cellular concrete, structure formation, plastic strength, rheological properties, mathematical equation, mechanochemical activation.

Introduction. One of the main tasks of today, along with solving environmental problems is the task of saving energy resources, including in the field of construction. In this regard, Ukraine, as in other countries, has adopted several regulations aimed at solving this problem. One such document strictly regulates the value of the coefficient of thermal resistance for the materials from 
which wall structures are made. According to this indicator, a number of the most common wall materials, such as lightweight concrete, ceramic, and silicate bricks, were not effective because they need to mount a thick wall. Therefore, in modern construction, one of the most effective and common materials is cellular concrete. The efficiency of aerated concrete is determined by its construction and operational properties. They, in turn, as well as properties of composite materials in general, are depending on the character of the structure of the material [1].

Analysis of recent research and publications. In [2] the hypothesis was expressed that the properties of cellular concrete are determined exclusively by the nature of the solid phase distributions. In the same works, chronological analysis of the structure-forming process of cellular concrete is given and it is shown that the so-called "primary" structure is formed before the end of the binder hardening period. To form a high-quality structure of cellular concrete, it is important to synchronize the processes of pore formation and increase the structural (plastic) strength of the mortar mixture. The speed and stability of pore formation in aerated concrete are ensured by the rate of gas formation, and in foam concrete - the stability of the technical foam. The kinetics of structural strength depends on the hardening rate of the binder, and it, in turn, largely depends on the rheological characteristics of the mortar mixture.

The rheological characteristics of the mortar mixture can be influenced by the amount of water in the mixture (water-cement or water-solid ratio). But the water-cement ratio not only affects the rheological characteristics of the mixture but also changes the kinetics of hydration of the binder and directly the strength of the material [3]. It is known that as the amount of binder increases, the strength of porous composite building materials increases. However, in porous concrete, the content of solid components, including binder, is limited to providing the required average density of the material. On the other hand, the binder, as a component of the raw material mixture, is the most valuable and its contribution to the cost of the material is the most significant. Another argument in favor of limiting the consumption of cement is due to the specifics of non-autoclaved foam concrete.

The hardening process of non-autoclaved foam concrete is accompanied by significant volume changes, which ultimately lead to the formation of cracks and reduced physical and mechanical properties of foam concrete. The main sources of volume changes are chemical reactions of cement hydration (contractile shrinkage) and wet shrinkage. Both types of volume changes are directly related to cement consumption. With increasing consumption of cement and in the process of its hydration, the number of hydrated neoplasms increases, the volume of which is less than the volume of the starting reagents, which is the cause of contraction [4]. On the other hand, as the number of cement increases, the amount of cement gel increases. Subsequently, after dehydration of the liquid, shrinkage cracks appear. The increased initial amount of water also contributes to the increase of shrinkage deformations due to the loss of moisture in the material. The amount of mixing water is also directly related to the consumption of cement - a component of the raw material mixture that has the greatest water consumption. To reduce the consumption of cement in the composition of the raw material mixture is filled [5].

Modern composite building materials cannot be imagined without the use of chemical additives. Chemical additives are introduced to give mortars the appropriate qualities [6,7].

Accelerating the set of strength for foam concrete is an urgent task. The need to use a soluble mixture with high values of water-cement ratio, caused by technological features of production. In addition, foaming agents affect the hydration process of cement and significantly slow down the curing time of foam concrete, which negatively affects the productivity of technological lines. It is possible to regulate these indicators at the expense of various chemical additives. The use of chemical additives is called "internal" activation [8].

In addition to chemical additives in the technology of building materials used other methods of activation. Such methods include activation of both raw materials and semi-finished products ("external" activation). All of them are associated with additional energy supply at certain stages of fabrication. The type, place of energy supply, and duration of impact is determined by the goal, technological features of production, economic parameters [9]. Mechanochemical activation has become widely used in the production of building materials. The issue of mechanochemical activation of raw materials is especially relevant in the technology of porous concrete. This is due to 
the conditions for ensuring the stability of the porous structure, accelerated set of structural strength, and a sufficient number of cementing tumors. There are also known methods of activating the binder or solution component in high-speed mixers [10]. Activation in such mixers also changes the rheological characteristics of the mixtures.

The aim. The research aimed to identify the patterns of influence of the rheology of the mortar component on the structural strength of the foam concrete mixture.

Materials and research methods. To achieve this goal, a three-factor experiment was conducted. Full information on variables, their levels, and intervals of variation are given in Table 1.

The choice of factors and intervals of their variation is made in such a way that allows you to compare different ways of preparing foam concrete. The first point of the experimental plan (all factors are at the lower level of variation) is taken as a control. The movement along the axis of the factor $\mathrm{X}_{1}$ allows you to determine the effect of the amount of filler on the properties of foam concrete. The movement along the axis of the factor $\mathrm{X}_{2}$ or $\mathrm{X}_{3}$ allows you to determine the degree of influence of activation methods ("internal" or "external") on the change in the properties of the foam concrete mixture and foam concrete. At other points in the recipe-technological field, the combined effect of the variables adopted in the experiment (mechanochemical activation) is indicated.

Table 1 - Factors, their levels, and intervals of variation

\begin{tabular}{|l|c|c|c|c|c|c|}
\hline \multirow{2}{*}{$\begin{array}{c}\text { The name of the } \\
\text { factor }\end{array}$} & Factor & \multirow{2}{*}{$\begin{array}{c}\text { Unit of } \\
\text { code }\end{array}$} & \multicolumn{3}{|c|}{ Levels of variation } & Interval of \\
measurement & & -1 & 0 & +1 & variation \\
\hline $\mathrm{X}_{1}-$ filler content & $\mathrm{F}$ & $\%$ & 0 & 15 & 30 & 15 \\
\hline $\begin{array}{l}\mathrm{X}_{2}-\text { the content } \\
\text { of the additive }\end{array}$ & $\mathrm{Ad}$ & $\%$ & 0 & 1,5 & 3 & 1,5 \\
\hline $\begin{array}{l}\mathrm{X}_{3}-\text { duration of } \\
\text { activation }\end{array}$ & $\mathrm{Ac}$ & $\mathrm{S}$ & 0 & 20 & 40 & 20 \\
\hline
\end{tabular}

Constant factors: the average density of the foam concrete mixture is $760 \pm 10 \mathrm{~g} / \mathrm{l}$, the diameter of the solution spread according to the Suttard viscometer is $270 \pm 10 \mathrm{~mm}$.

Portland cement M500 of the Odessa Cement Plant was used in the experiment. As a filler, carbonate sand with a size of less than $0.63 \mathrm{~mm}$, and a chemical additive of complex action «Relaxol Universal».

Research results. The study of the influence of the factors accepted in the experiment on the value of the structural strength of foam concrete was performed by measuring the plastic strength of the foam concrete mixture using a conical plastometer MSU. Measurements of the plastic strength of foam concrete were started 6 hours after the preparation of foam concrete and completed after 24 hours with measurement intervals every 2 hours. The value of plastic strength was calculated as the arithmetic mean of five measurements. The matrix of the experimental design and plastic strength of foam concrete $(\mathrm{kPa})$ are shown in Table 2.

Based on the results of experimental data, graphs of the kinetics of plastic strength of foam concrete in each line of the plan are constructed. The kinetics of the plastic strength of foam concrete is shown in Figure 1.

In this form, the obtained dependencies are difficult to analyze, especially to determine the influence of variables on the kinetics of plastic strength of foam concrete. Therefore, the following method was used to process and present the results of the experiment.

After obtaining a family of lines, each was approximated by a polynomial of the third degree of plastic strength of foam concrete over time. The coefficient of approximation is not less than 0.97. After that, the derivatives were determined: the first derivative - the rate of growth of plastic strength and the second derivative - the intensity (acceleration) of growth of plastic strength. The equations of plastic strength, rate, and intensity of growth of plastic strength of foam concrete are shown in Table 3.

Based on these equations, graphs of changes in the speed and intensity of the set of plastic strength over time, which are shown in Fig. 2 and Fig. 3. From the graphs (Fig. 1), as expected, it is seen that the plastic strength of the foam concrete mixture increases over time. The influence of 


\section{BUILDING MATERIALS AND TECHNIQUES}

variable factors on the kinetics of plastic strength and its derivatives is also obvious. It should be noted that some lines of the experiment change the nature of the dependence. This is especially true of the intensity of change in plastic strength (Fig. 3) when the intensity is not accelerating, but slowing down.

Table 2 - Plastic strength of foam concrete, $\mathrm{kPa}$

\begin{tabular}{|c|c|c|c|c|c|c|c|c|c|c|c|c|c|}
\hline \multirow{3}{*}{$\begin{array}{l}\stackrel{0}{.} \\
. \Xi \\
\frac{01}{2}\end{array}$} & \multicolumn{3}{|c|}{ Indexes } & \multirow{2}{*}{\multicolumn{10}{|c|}{ Terms of measurements, hours }} \\
\hline & \multirow{2}{*}{$\frac{\mathrm{X}_{1}}{\mathrm{~F}}$} & \multirow{2}{*}{$\begin{array}{l}\mathrm{X}_{2} \\
\mathrm{Ad}\end{array}$} & \multirow{2}{*}{$\frac{X_{3}}{A c}$} & & & & & & & & & & \\
\hline & & & & 6 & 8 & 10 & 12 & 14 & 16 & 18 & 20 & 22 & 24 \\
\hline 1 & - & - & - & 4,9 & 6,2 & 23 & 38,7 & 53,8 & 75,5 & 108 & 129 & 206 & 286 \\
\hline 2 & + & - & - & 4,9 & 6,2 & 10 & 21 & 30,6 & 54,5 & 92,5 & 98,4 & 144 & 200 \\
\hline 3 & - & + & - & 4,9 & 5,9 & 9,8 & 29,5 & 50,5 & 78,8 & 114 & 175 & 190 & 270 \\
\hline 4 & + & + & - & 5,6 & 7,5 & 14 & 28,9 & 50 & 92 & 102 & 128 & 218 & 243 \\
\hline 5 & - & - & + & 4,6 & 10,5 & 20 & 50 & 69 & 87 & 114 & 175 & 197 & 210 \\
\hline 6 & + & - & + & 4,9 & 11 & 14 & 31 & 45,5 & 82 & 126 & 201 & 220 & 230 \\
\hline 7 & - & + & + & 5 & 15 & 27 & 59 & 78 & 128 & 164 & 223 & 243 & 328 \\
\hline 8 & + & + & + & 1,2 & 20,3 & 45 & 58,5 & 107 & 140 & 157 & 256 & 361 & 407 \\
\hline 9 & - & 0 & 0 & 7 & 22,5 & 34 & 70 & 113 & 151 & 269 & 459 & 502 & 512 \\
\hline 10 & + & 0 & 0 & 7 & 16 & 24 & 44 & 76,1 & 131 & 137 & 144 & 154 & 246 \\
\hline 11 & 0 & - & 0 & 7,2 & 12 & 27 & 47,3 & 92 & 134 & 151 & 167 & 243 & 303 \\
\hline 12 & 0 & + & 0 & 18 & 34 & 66 & 121,5 & 161 & 256 & 321 & 400 & 470 & 556 \\
\hline 13 & 0 & 0 & - & 6,2 & 9,2 & 21 & 34 & 62 & 90 & 103 & 164 & 227 & 253 \\
\hline 14 & 0 & 0 & + & 9 & 14 & 36 & 56,5 & 111 & 138 & 167 & 212 & 262 & 305 \\
\hline 15 & 0 & 0 & 0 & 10 & 23 & 41 & 75,5 & 95 & 124 & 132 & 150 & 262 & 331 \\
\hline
\end{tabular}

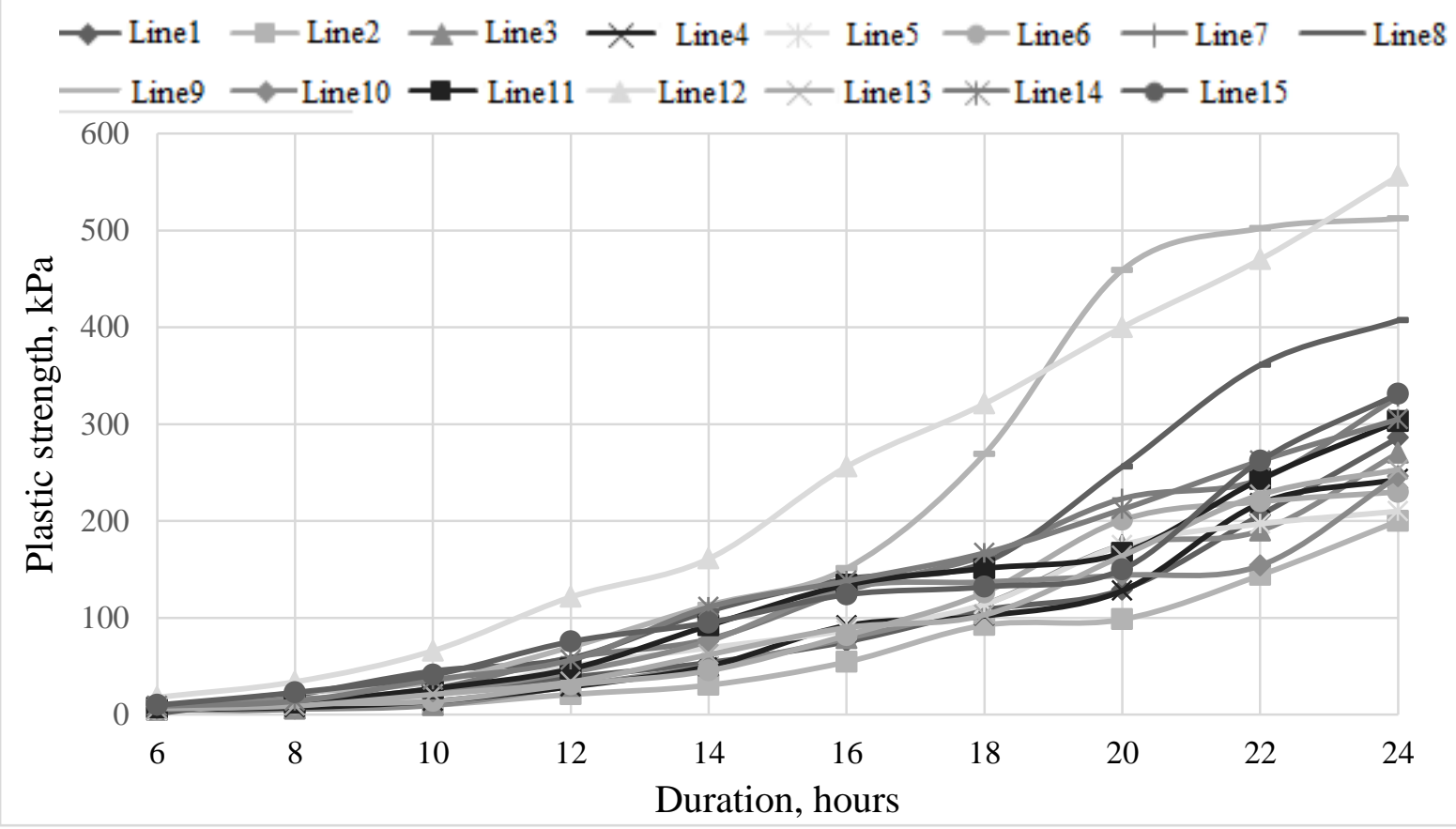

Fig 1. Kinetics of structural strength of foam concrete 
Table 3 - Equations of plastic strength and its derivatives

\begin{tabular}{|c|c|c|c|c|}
\hline $\begin{array}{c}\text { № } \\
\text { plan } \\
\text { line }\end{array}$ & Plastic strength, $\mathrm{kPa}$ & $\begin{array}{c}\text { The rate of increase of } \\
\text { plastic strength, } \\
\mathrm{kPa} / \mathrm{h}\end{array}$ & $\begin{array}{c}\text { The intensity of the } \\
\text { increase in plastic } \\
\text { strength, } \mathrm{kPa} / \mathrm{h}^{2}\end{array}$ & $\begin{array}{c}\text { Approxim } \\
\text { ation } \\
\text { coefficient }\end{array}$ \\
\hline 1 & $0,35 \mathrm{t}^{3}-5,24 \mathrm{t}^{2}+40,1 \mathrm{t}-29,3$ & $1,05 \mathrm{t}^{2}-10,4 \mathrm{t}+40,1$ & $2,1 \mathrm{t}-10,4$ & 0,99 \\
\hline 2 & $0,19 \mathrm{t}^{3}-1,4 \mathrm{t}^{2}+6,2 \mathrm{t}+16$ & $0,57 \mathrm{t}^{2}-2,8 \mathrm{t}+6,2$ & $1,04 \mathrm{t}-2,8$ & 0,99 \\
\hline 3 & $0,13 \mathrm{t}_{3}+2,28 \mathrm{t}^{2}-24,8 \mathrm{t}+47,2$ & $0,39 \mathrm{t}^{2}+4,6 \mathrm{t}-24,8$ & $0,78 \mathrm{t}+4,6$ & 0,99 \\
\hline 4 & $0,16 \mathrm{t}^{3}+0,99 \mathrm{t}^{2}-10,06 \mathrm{t}+30,8$ & $0,48 \mathrm{t}^{2}+2 \mathrm{t}-10,06$ & $0,96 \mathrm{t}+2$ & 0,98 \\
\hline 5 & $-0,12 \mathrm{t}^{3}+8,9 \mathrm{t}^{2}-57,3 \mathrm{t}+70$ & $-0,36 \mathrm{t}^{2}+17,8 \mathrm{t}-57,3$ & $-0,72 \mathrm{t}+17,8$ & 0,98 \\
\hline 6 & $-0,06 \mathrm{t}^{3}+9,6 \mathrm{t}^{2}-79,6 \mathrm{t}+110,9$ & $-0,27 \mathrm{t}^{2}+19,2 \mathrm{t}-19,6$ & $-0,54 \mathrm{t}+19,2$ & 0,97 \\
\hline 7 & $0,01 \mathrm{t}^{3}+7,04 \mathrm{t}^{2}-42,5 \mathrm{t}+48,4$ & $0,03 \mathrm{t}^{2}+14 \mathrm{t}-42,5$ & $0,06 \mathrm{t}+14$ & 0,99 \\
\hline 8 & $0,29 \mathrm{t}^{3}+0,88 \mathrm{t}^{2}+4,2 \mathrm{t}+7,1$ & $0,78 \mathrm{t}^{2}+1,7 \mathrm{t}+4,2$ & $1,56 \mathrm{t}+1,7$ & 0,99 \\
\hline 9 & $-0,15 \mathrm{t}^{3}+20 \mathrm{t}^{2}-167 \mathrm{t}+227$ & $-0,42 \mathrm{t}^{2}+14,2 \mathrm{t}-167$ & $0,84 \mathrm{t}+14,2$ & 0,96 \\
\hline 10 & $-0,07 \mathrm{t}^{3}+6,6 \mathrm{t}^{2}-27,7 \mathrm{t}+31,2$ & $-0,21 \mathrm{t}^{2}+13,2 \mathrm{t}-27,7$ & $-0,42 \mathrm{t}+13,2$ & 0,96 \\
\hline 11 & $0,04 \mathrm{t}^{3}+5,3 \mathrm{t}^{2}-25,1 \mathrm{t}+29,5$ & $0,12 \mathrm{t}^{2}+10,6 \mathrm{t}-25,1$ & $0,24 \mathrm{t}+10,6$ & 0,99 \\
\hline 12 & $-0,22 \mathrm{t}^{3}+19 \mathrm{t}^{2}-105 \mathrm{t}+102$ & $-0,66 \mathrm{t}^{2}+38 \mathrm{t}-105$ & $-1,32 \mathrm{t}+38$ & 0,99 \\
\hline 13 & $0,12 \mathrm{t}^{3}+2,4 \mathrm{t}^{2}-17,7 \mathrm{t}+40,4$ & $0,38 \mathrm{t}^{2}+4,8 \mathrm{t}-17,7$ & $0,72 \mathrm{t}+4,8$ & 0,99 \\
\hline 14 & $-0,12 \mathrm{t}^{3}+10,5 \mathrm{t}^{2}-58 \mathrm{t}+58$ & $-0,36 \mathrm{t}^{2}+38 \mathrm{t}-105$ & $-0,72 \mathrm{t}+21$ & 0,99 \\
\hline 15 & $0,32 \mathrm{t}^{3}-4,6 \mathrm{t}^{2}+62,8 \mathrm{t}-64,4$ & $0,96 \mathrm{t}^{2}-8,2 \mathrm{t}+62,8$ & $1,92 \mathrm{t}-8,2$ & 0,98 \\
\hline
\end{tabular}

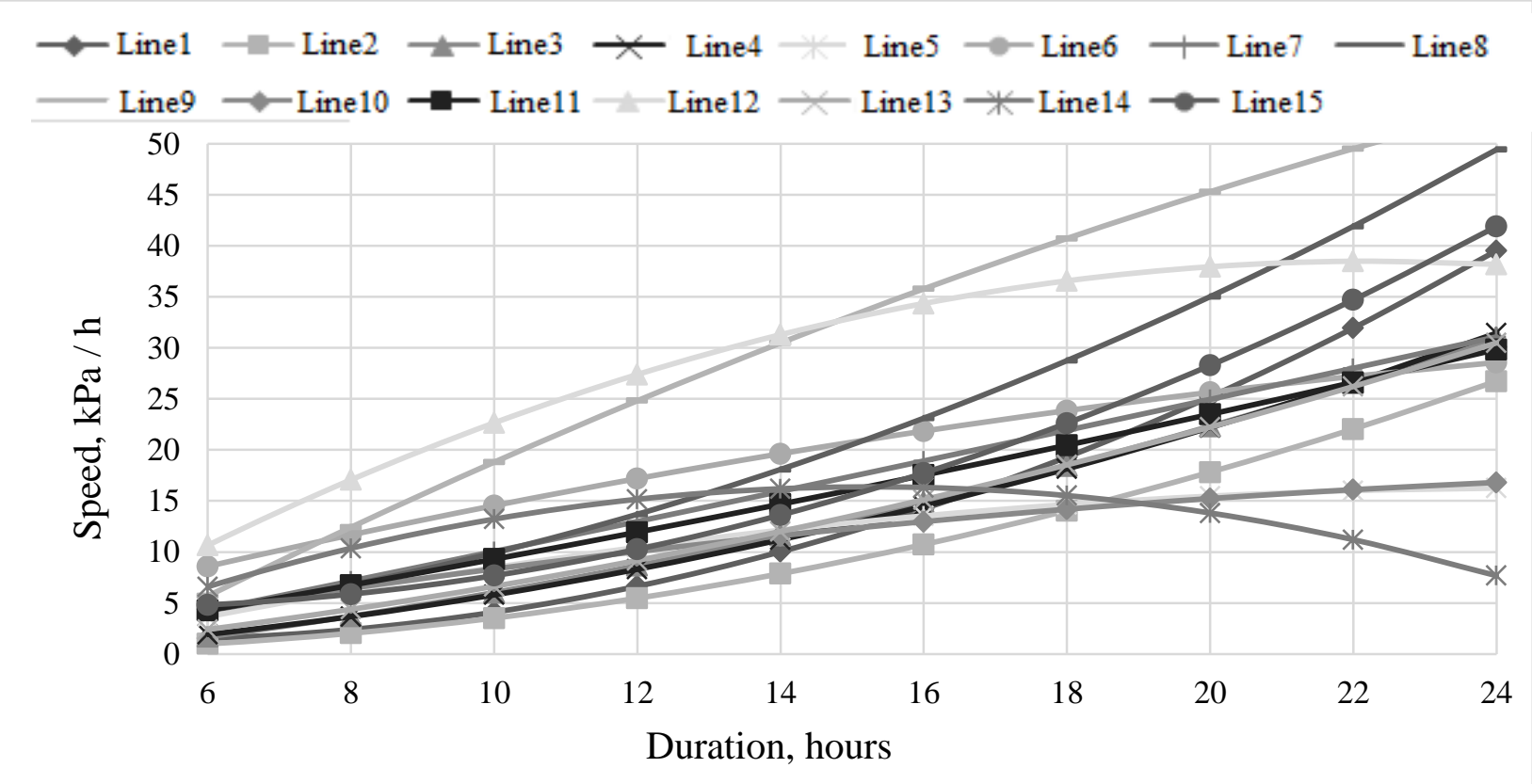

Fig. 2. The speed of plastic strength of foam concrete

Due to the fact that the graphical dependencies are shown in Figures $2 \ldots 3$ are difficult to analyze, and also because they do not reflect the full picture of the influence of the studied factors on the plastic strength of foam concrete and its derivatives, using the values of table 3 , was synthesized 4-x factorial plan of the Box-Benkill experiment type B-4. As the fourth variable factor the factor of the term of endurance of foam concrete from the moment of its preparation was entered, with levels of variation: lower $-8 \mathrm{~h}$, average $-16 \mathrm{~h}$, top $-24 \mathrm{~h}$. Factor code $-\tau$.

The matrix and the results of the synthesis plan are shown in Table 4.

As a result of mathematical processing in the COMPEX system, mathematical models of the logarithm of plastic strength, speed, and intensity of the set of plastic strength are built.

Based on the obtained mathematical models, the isosurfaces of these properties are constructed. The isosurface of plastic strength is shown in Figure 4. 


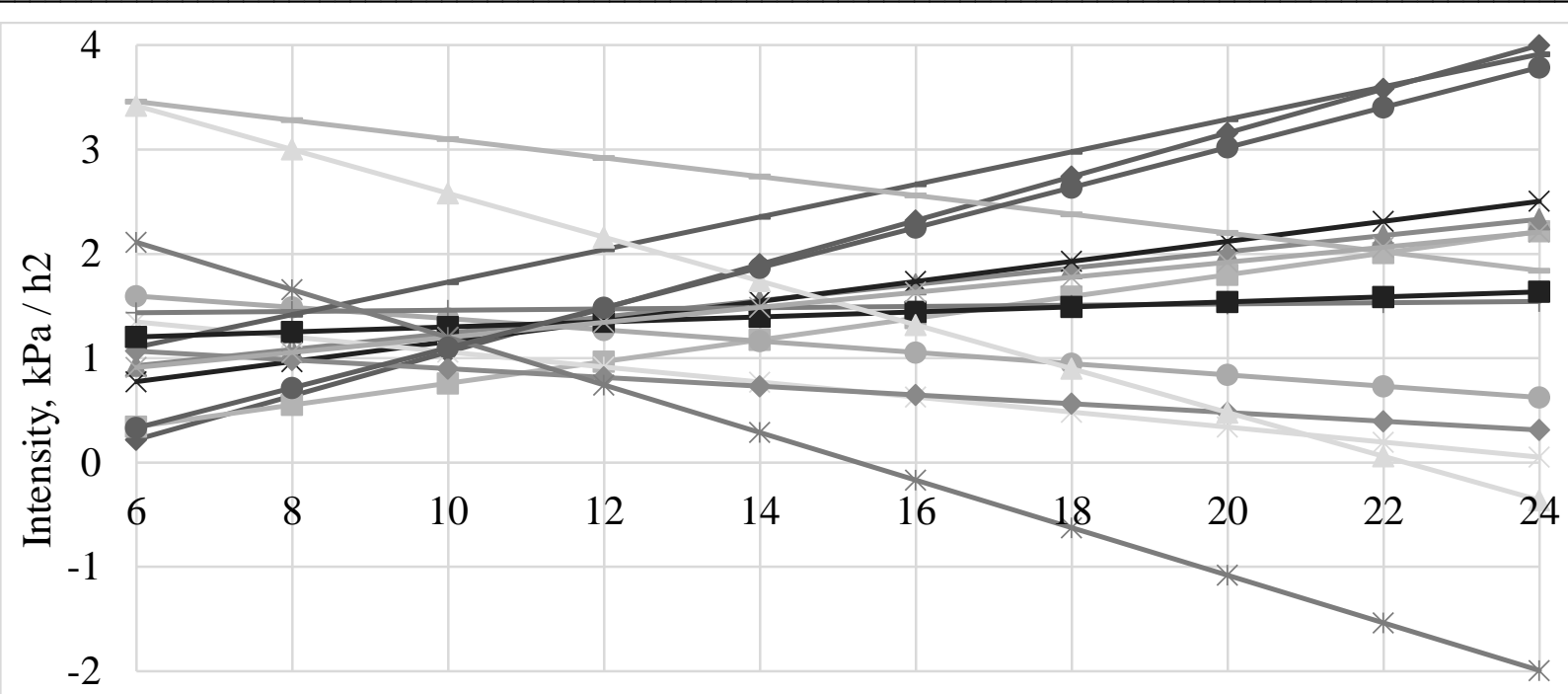

Duration, hours

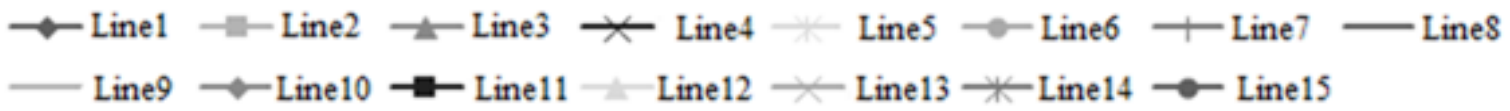

Fig. 3. The intensity of plastic strength of foam concrete

Table 4 - Matrix of planning of the experiment, plastic durability, speed, and intensity of growth of plastic durability of foam concrete

\begin{tabular}{|c|c|c|c|c|c|c|c|c|c|c|c|c|}
\hline \multirow{3}{*}{$\begin{array}{l}0 \\
\Xi \\
\stackrel{0}{2}\end{array}$} & \multicolumn{3}{|c|}{ Indexes } & \multicolumn{3}{|c|}{$\begin{array}{c}\text { Plastic } \\
\text { strength, } \mathrm{kPa}\end{array}$} & \multicolumn{3}{|c|}{$\begin{array}{l}\text { Speed, } \\
\mathrm{kPa} / \mathrm{h}\end{array}$} & \multicolumn{3}{|c|}{$\begin{array}{l}\text { Intensity, } \\
\mathrm{kPa} / \mathrm{h}^{2}\end{array}$} \\
\hline & $\mathrm{F}$ & $\mathrm{Ad}$ & Ac & \multicolumn{9}{|c|}{ Time, hours } \\
\hline & $\overline{\mathrm{X}_{1}}$ & $\mathrm{X}_{2}$ & $\overline{X_{3}}$ & 8 & 16 & 24 & 8 & 16 & 24 & 8 & 16 & 24 \\
\hline 1 & - & - & - & 13,5 & 70,4 & 275,3 & 2,4 & 14,3 & 39,5 & 0,6 & 2,3 & 4 \\
\hline 2 & + & - & - & 7,2 & 53,5 & 198,5 & 2 & 10,7 & 26,7 & 0,6 & 1,4 & 2,2 \\
\hline 3 & - & + & - & 6,1 & 76,7 & 256,2 & 3,7 & 14,9 & 31 & 1,1 & 1,7 & 2,3 \\
\hline 4 & + & + & - & 9,6 & 77,9 & 257,1 & 3,7 & 14,5 & 31,4 & 1 & 1,7 & 2,5 \\
\hline 5 & - & - & + & 12 & 94 & 216,2 & 6,2 & 13,5 & 16,3 & 1,2 & 0,6 & 0,1 \\
\hline 6 & + & - & + & 5,8 & 104,9 & 290,1 & 11,7 & 21,8 & 28,6 & 1,5 & 1,1 & 0,6 \\
\hline 7 & - & + & + & 16,4 & 121,2 & 322,2 & 7,1 & 18,9 & 31,1 & 1,4 & 1,5 & 1,5 \\
\hline 8 & + & + & + & 24,6 & 148,7 & 462,4 & 6,8 & 23,1 & 49,4 & 1,4 & 2,7 & 3,9 \\
\hline 9 & - & 0 & 0 & 9,4 & 206,1 & 566,5 & 12,6 & 36,1 & 53,9 & 4,7 & 5,3 & 6 \\
\hline 10 & + & 0 & 0 & 19,6 & 99,1 & 220 & 6,4 & 13 & 16,8 & 1 & 0,6 & 0,3 \\
\hline 11 & 0 & - & 0 & 18,8 & 114,9 & 303,3 & 6,7 & 17,5 & 29,8 & 1,3 & 1,4 & 1,6 \\
\hline 12 & 0 & + & 0 & 36,5 & 238,5 & 548,5 & 15,7 & 33,4 & 42,7 & 2,7 & 1,7 & 0,6 \\
\hline 13 & 0 & 0 & - & 11,4 & 86,3 & 265,7 & 4,5 & 15,6 & 31,6 & 1,1 & 1,6 & 2,2 \\
\hline 14 & 0 & 0 & + & 20,5 & 132,6 & 305,5 & 17,6 & 41,1 & 60 & 1,5 & 0,9 & 0,4 \\
\hline 15 & 0 & 0 & 0 & 43,6 & 120,2 & 334,6 & 5,9 & 17,7 & 41,9 & 0,7 & 2,3 & 3,8 \\
\hline
\end{tabular}

The figure highlights two areas A and B. Area A is limited to the values of plastic strength, at which it is advisable to cut the foam concrete mass into individual products. The lower limit (30 $\mathrm{kPa})$ is the minimum plastic strength regulated by BN-277-80 "Instructions for the manufacture of porous concrete products", at which you can cut the array.

The upper limit $(100 \mathrm{kPa})$ is designed for the following reasons: such structural strength of the raw material does not separate parts of the array at the endpoints of the string and adheres to the correct geometric shapes of products and the accuracy of their dimensions. Area B corresponds to the strength of foam concrete, which allows manual stripping of products made in individual forms. 


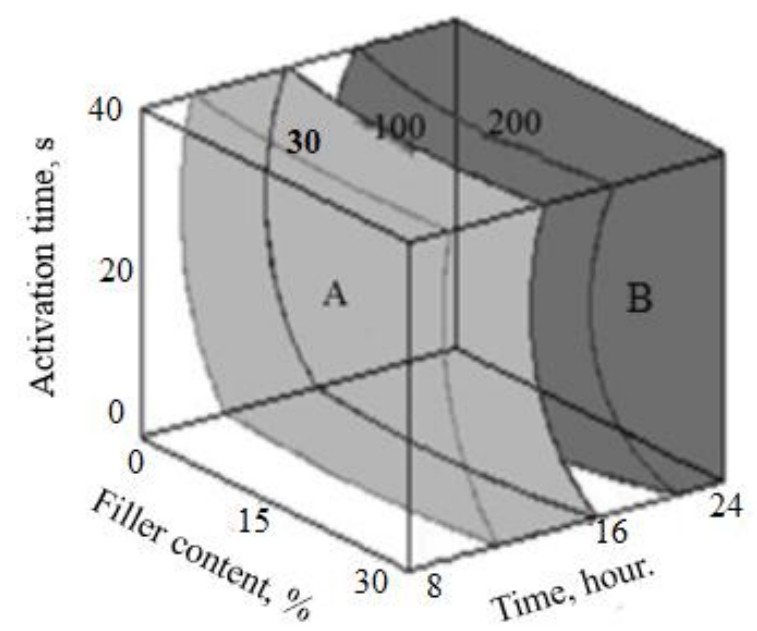

Fig. 4. Isosurfaces of plastic strength $(\mathrm{kPa})$ of foam concrete at the content of the additive of the hardening accelerator of $1,5 \%$

Conclusions and prospects for further research. According to the results of the experiment and the applied methodological method of processing the results of the experiment to study the kinetics of the set of the structural strength of foam concrete in the recipe-technological field, the characteristic areas of plastic strength are identified. This allowed using in practice the results obtained in the production of foam concrete by various technologies: "cutting", "foundry", in the manufacture of products in individual forms.

It was found that the mechanochemical activation of the soluble component is an important technological technique that allows you to control the rheological characteristics of foam concrete. Due to the identified joint interaction of factors that changed in the experiment, it was possible to reduce the maturation of the raw mass to the required plastic strength by 4-7 hours.

The received array of information does not allow it to carry out its full analysis within one article. In this paper, we have generally focused on the kinetics of plastic strength. The analysis of changes in the speed and intensity of plastic strength deserves no less attention. This, first of all, concerns the identification of the reasons for the change like the influence of the studied prescription-technological factors on the properties of the foam concrete mixture. In addition, given that the period of structural organization of aerated concrete is crucial in the formation of its physical and mechanical properties, it is important to conduct a joint analysis of the experimental rheological characteristics of foam concrete mixture and strength of foam concrete (the experiment also investigated the basic physical and mechanical properties of foam concrete). The results of this analysis will be presented in the next article.

\section{References}

[1] V. Vyrovoy, O. Korobko, O. Ielkin, "Technological events in structural evolution of building composites", Web of Conferences Open Access Journal "MATEC Web Conferences", EDP Science, V. 116, 2017. DOI 10.1051/matecconf/201711601021.

[2] V.I. Martinov, "Modelyuvannya protsesu strukturoutvorennya pinobetonu ta metody otsinky kharakteru yoho struktury", Visnyk Odes'koyi Derzhavnoyi akademiyi budivnytstva ta arkhitektury, vol. 67, pp. 78-83, 2017.

[3] R.F. Runova, YU.L. Nosovs'kij, L.J. Dvorkin, O.L. Dvorkin, V'yazhuchi rechovini : Pidruchnik. K.: Osnova, 2012.

[4] A.V. Volzhens'kyy, YU.S. Burov, V.S Kolokol'nykov, Mineral'ni v'yazki rechovyny. M.: Budvydav, 1979.

[5] V.M. Vyrovoy, V.S. Dorofyeyev, V.H. Sukhanov, Kompozytsiyni budivel'ni materialy ta konstruktsiyi: struktura, samoorhanizatsiya, vlastyvosti. Odesa: TES, 2010.

[6] M. Stechyshyn, M. Sanytskyy, O. Poznyak, "Durability properties of high volume fly ash selfcompacting fiber reinforced concretes", East European Journal of Enterprise Technologies, 3/11(75), pp. 49-53, 2015. 
[7] S.V. Koval, Modeling and optimization of composition and properties of modified concrete: monograph. Odessa: Astroprint, 2012.

[8] E. Krylov, V. Martynov, M. Mykolaiets, O. Martynova, O. Vietokh, "Influence of modification of the solid component on the properties of non-autoclaved aerated concrete", Eastern-European Journal of Enterprise Technologies, vol. 3, no. 6 (99), pp. 53-59, 2019. doi: 10.15587 / 1729-4061.2019.171012.

[9] V.V. Opyekunov, Konstruktsiyno-teploizolyatsiyni budivel'ni materialy na osnovi aktyvovanykh syrovynnykh komponentiv. K.: „Akademperiodyka”, 2001.

[10] I. Barabash, D. Harashenko, "Mechanoactivation of portland cement in the technology of manufacturing the self-compacting concrete", Croatian Regional Development Journal, no. 3/6 (93), pp. 12-17, 2018.

\title{
КІНЕТИКА РЕОЛОГІЧНИХ ХАРАКТЕРИСТИК ПІНОБЕТОННОЇ СУМІШІ
}

\author{
${ }^{1}$ Мартинов B.I., д.Т.н., доцент, \\ ogasa_psk@ukr.net, ORCID: 0000-0002-9674-7920 \\ ${ }^{2}$ Мартинова О.Б., к.т.н., доцент, \\ pingu_@ukr.net, ORCID: 0000-0001-7324-2543 \\ ${ }^{3}$ Слькін В.В., керівник проектного відділу \\ vladislav.elkin.ogasa@gmail.com, ORCID: 0000-0001-5725-4763 \\ ${ }^{1}$ Макарова С.С., к.т.н., доцент, \\ svetlana.makarova@ukr.net, ORCID: 0000-0003-3237-1431 \\ ${ }^{1}$ Казмірчук Н.В., к.т.н., ст. викладач, \\ nkazmirchuk8@gmail.com, ORCID: 0000-0003-0930-2059 \\ ${ }^{1}$ Одеська державна академія будівництва та архітектури \\ вул. Дідріхсона, 4, м. Одеса, 65029, Україна \\ ${ }^{2}$ Одеський державний аграрний університет \\ вул. Пантелеймонівська 13, м. Одеса, 65074, Україна \\ ${ }^{3}$ ТОВ «ТД Інкрафт»», \\ пров. Газовий, 8, Одеса, 65074, Україна
}

\begin{abstract}
Анотація. Наведено результати експериментальних досліджень, метою яких було вивчення впливу змінних рецептурно-технологічних факторів на реологічні характеристики пінобетонної суміші, зокрема структурну міцність. Цьому передує аналіз процесу структуроутворення пористих бетонів. Внаслідок чого показано, що властивості пористих бетонів визначаються характером розподілів твердої складової. Структура ж твердої фази формується на ранніх термінах формування комірчастих виробів і залежить від реологічних характеристик розчинової і комірчастої суміші. У технології пористих бетонів важливою $є$ синхронізація процесів пороутворення та наростання пластичної (структурної) міцності, що також пов'язано із зміною реологічних властивостей суміші. Із застосуванням методів математичної статистики вивчено вплив вмісту наповнювача у суміші 3 цементом, вміст комплексної добавки та вплив механохімічної активації на кінетику пластичної міцності пінобетонної суміші. Побудовано кінетичні залежності пластичної міцності пінобетонної суміші в інтервалі 6-24 години з моменту виготовлення. Кожна із 15 кривих проаксимована поліномом 3-го ступеня. На основі отриманих залежностей вони диференційовані першою та другою похідною. В результаті отримані рівняння швидкості та інтенсивності (прискорення) пластичної міцності пінобетонної суміші. За результатами попереднього експерименту, який проводився за трьохфакторним планом, був синтезований 4-х факторний план, в якому як четвертий фактор прийнятий термін витримки пінобетонної суміші. У матрицю було введено розраховані теоретичні значення характеристик структурної міцності пінобетонної суміші. В результаті були розраховані математичні моделі пластичної міцності, швидкості та інтенсивності пластичної міцності пінобетонної суміші та візуалізовано вплив змінних факторів, що вивчаються на ізоповерхнях цих властивостей. Аналіз цих залежностей дозволив
\end{abstract}


визначити характерні рецептурно-технологічні умови одержання пінобетонної суміші 3 необхідними значеннями пластичної міцності.

Ключові слова: ніздрюватий бетон, структуроутворення, пластична міцність, реологічні властивості, математична модель, механохімічна активація.

\title{
КИНЕТИКА РЕОЛОГИЧЕСКИХ ХАРАКТЕРИСТИК ПЕНОБЕТОННОЙ СМЕСИ
}

\author{
${ }^{1}$ Мартынов В.И., д.т.н., доцент, \\ ogasa_psk@ukr.net, ORCID: 0000-0002-9674-7920 \\ ${ }^{2}$ Мартынова Е.Б., к.т.н., доцент, \\ pingu_@ukr.net, ORCID: 0000-0001-7324-2543 \\ ${ }^{3}$ Елькин В.В., руководитель проектного отдела, \\ vladislav.elkin.ogasa@gmail.com, ORCID: 0000-0001-5725-4763 \\ ${ }^{1}$ Макарова С.С., к.Т.Н., доцент, \\ svetlana.makarova@ukr.net, ORCID: 0000-0003-3237-1431 \\ ${ }^{1}$ Казмирчук Н.В., к.т.Н., ст. преподаватель, \\ nkazmirchuk8@gmail.com, ORCID: 0000-0003-0930-2059 \\ ${ }^{1}$ Одесская государственная академия строительства и архитектуры \\ ул. Дидрихсона, 4, г. Одесса, 65029, Украина \\ ${ }^{2}$ Одеський государственный аграрный университет \\ ул. Пантелеймоновская, 13, г. Одесса, 65074, Украина \\ ${ }^{3}$ ООО «ТД Инкрафт»», \\ пер. Газовый, 8, Одесса, 65000, Украина
}

\begin{abstract}
Аннотация. Приведены результаты экспериментальных исследований, целью которых было изучение влияния переменных рецептурно-технологических факторов на реологические характеристики пенобетонной смеси, в частности, структурную прочность. Этому предшествует анализ процесса структурообразования ячеистых бетонов. В результате чего показано, что свойства ячеистых бетонов определяются характером распределений твердой составляющей. Структура же твердой фазы формируется на самых ранних сроках формирования ячеистых изделий и зависит от реологических характеристик растворной и ячеистой смеси. В технологии ячеистых бетонов важной является синхронизация процессов порообразования и нарастания пластической (структурной) прочности, что также связано с изменением реологических свойств смеси. С применением методов математической статистики изучено влияние содержания наполнителя в смеси с цементом, содержание комплексной добавки и влияние механохимической активации на кинетику пластической прочности пенобетонной смеси. Построены кинетические зависимости пластической прочности пенобетонной смеси в интервале $6 . .24$ часа с момента изготовления. Каждая из 15 кривых проаксимирована полиномом 3-й степени. На основе полученных зависимостей они дифференцированы первой и второй производной. В результате получены уравнения скорости и интенсивности (ускорения) пластической прочности пенобетонной смеси. По результатам предыдущего эксперимента, проводившегося по трехфакторному плану, был синтезирован 4-х факторный план, в котором в качестве четвертого фактора принят срок выдержки пенобетонной смеси. В матрицу были введены рассчитанные теоретические значения характеристик структурной прочности пенобетонной смеси. В результате были рассчитаны математические модели пластической прочности, скорости и интенсивности пластической прочности пенобетонной смеси и визуализировано влияние переменных факторов, изучаемых на изоповерхностях этих свойств. Анализ этих зависимостей позволил определить характерные рецептурно-технологические условия получения пенобетонной смеси с необходимыми значениями пластической прочности.

Ключевые слова: ячеистый бетон, структурообразование, пластическая прочность, реологические свойства, математическое уравнение, механохимическая активация.
\end{abstract}

Стаття надійшла до редакції 11.11.2021 